\title{
MATCHING THE CONTROLLER ROLE: INDIVIDUALS VS COMPANIES
}

\author{
Ariel LA PAZ (D) ${ }^{*}$, Daniela GRACIA ${ }^{1}$, Jonathan VÁSQUEZ (D) 2, 3 \\ ${ }^{1}$ Department of Management Control and Information Systems, \\ Faculty of Business and Economics, University of Chile, Santiago, Chile \\ ${ }^{2}$ Escuela de Auditoría, Universidad de Valparaíso, Valparaíso, Chile \\ ${ }^{3}$ Centro de Investigación en Negocios y Ciencias Empresariales, \\ Universidad de Valparaíso, Valparaíso, Chile
}

Received 19 December 2019; accepted 25 June 2020

\begin{abstract}
Finding a good match in the C-Suite is critical for maximizing business value and capitalizing on competitive advantages. This study analyzes the roles of controllers in organizational descriptions and executives' profiles, as they both define the position and craft the profession. This paper proposes a framework to describe and classify the existing controller types based on an extended review and description of the available literature. Then, using a clustering method based on the semisupervised $k$-means, we mapped a sample of 45 controllers to their dominant profile and contrasted individuals' characteristics against the companies' definitions of the role. This study reveals that the understanding of the types of controllers, which is usually presented as a dichotomy, may lead to mismatches between what is needed and what is performed. The clustering analysis reveals a significant mismatch between individuals and the organizations defining the role. The framework and clustering method could be used for multiple purposes, such as evaluating what type of controller an individual is or a company needs, which would improve recruitment processes to achieve better matches. The framework expands the identification of controllers from a dichotomy to a gradual classification and describes four controller profiles. This perspective further describes the role and validates the framework using data mining tools.
\end{abstract}

Keywords: managerial accounting, controller profile, controller role, recruitment and selection, professional development, clustering profile.

JEL Classification: M12, M41, J44, L84, O15, C82.

\section{Introduction}

In the rapid and more recent evolution of management control theory and practice, the definitions of the roles and responsibilities of the highest-level professionals and executives working as Controllers has changed and adapted, ranging from archetypes named bean counters,

*Corresponding author. E-mail: lapaz@fen.uchile.cl

This is an Open Access article distributed under the terms of the Creative Commons Attribution License (http://creativecommons. org/licenses/by/4.0/), which permits unrestricted use, distribution, and reproduction in any medium, provided the original author and source are credited. 
scorekeepers, and watchmen to consultants, advisors and business partners (Colton, 2001; Graham et al., 2012), with important variations according to the business unit (Indjejikian \& Matějka, 2006; Morales \& Lambert, 2013) or the geographical location of the company (Azan \& Bollecker, 2011; Goretzki et al., 2013; Guenther, 2013; Janin, 2017). The role, however, has usually been presented as a dichotomy between the bean counter and the business partner (Janin, 2017), but the literature recognizes the need for a better understanding of the factors causing the variations of the role (Hartmann \& Maas, 2011; Lambert \& Sponem, 2012). Fourné et al. (2018) studied the definitions of controllers' roles and developed scales to empirically test three roles - business partner, watchdog, and bean counter - while Lambert and Sponem (2012) found four types of roles - discrete, safeguard, partner and omnipotent - according to the authority and internal client's definition. Failing to match the right profiles would produce gaps in the performances of companies and frustration for individuals, and educational institutions could miss the focus of the evolution and over/under emphasize the abilities, skills and tools that professionals and organizations need to succeed. Our motivation is to describe and conceptualize the options that companies and individuals face when defining the position and crafting a professional career, since the archetypes identified in the literature and management control theory indicate that there are intermediate expressions of the role (Byrne \& Pierce, 2007) as companies define it and as professionals perform it in a way that is affected by both parties (Hopper, 1980; Lambert \& Sponem, 2012; Rieg, 2018). Hence, the research questions that the authors aim to answer are the following: What are the different types of controllers and their characteristics? Which factors shape the type of role that controllers perform in an organization? Once these factors are found, are these factors good predictors for identifying the types of controllers? How similar are the individuals' characteristics and the companies' needs for the role? By answering these questions, we will be able to conceptualize the types of profiles that better fit the organizational contexts and provide a means for companies to better describe and promote the type of controller they need. Professionals in the field may use our results to make informed decisions and shape their careers, and educational institutions may revise the designs of their academic and specialization programs to satisfy the new and future demands of companies for the management control function. Management control theorists may also find the classification useful when further studying the construction of the profile and the roles of controllers and management accountants in organizations.

The authors conducted an exploratory sequential study with two main stages to answer the research questions. The first phase of the study provided a description of the different controller roles by synthesizing the literature in a conceptual framework of controllers and validated the framework with scholars and top executives in the area. In the second phase, we used the conceptual framework as a theoretical base to design a questionnaire and to collect empirical data to classify a sample of controller executives using a clustering technique.

The structure of the remainder of this article is as follows. The next section introduces the differences in the understanding of the controller and presents a synthesis of the literature on controller profiles. Section two, develops the first phase of the research, and presents a validated framework. The third section describes how the framework is used to classify a 
sample of controllers from two perspectives: the characteristics of individuals and companies' definitions of the role. Then, in section number four, a comparative analysis between the perspectives of individuals and companies is performed, section five presents the discussion and limitations of the study; and finally, the conclusions are presented.

\section{State of the art}

The term "controller" has been used to identify different professionals who analyze data and produce information to support decision-making processes. The appearance of controllers in companies is usually related to accounting, since accountants have transitioned from recording data for financial analysis to management accounting to support decision-making. Some studies name this role the financial controller (Graham et al., 2012), others name it the business unit controller (ten Rouwelaar et al., 2008), and others name it the corporate controller (Zoni \& Merchant, 2007). The role of controllers is also associated with a broader and more strategic function that seeks to maintain the logic and rationality in decision making processes by adding value to the managerial and administrative tasks and being the anchor that deploys the business strategy in the literature that studies the business partner (Goretzki et al., 2013; Granlund \& Lukka, 1997; Janin, 2017; ten Rouwelaar et al., 2018). Technological advances facilitated the accomplishment of the role defined in the early 1970s as a qualified analyst and as a reasonably precise forecaster (Crampton, 1970) who, due to the digitalized and integrated information systems, focuses more on the analysis and interpretation of information floods coming in high volumes, velocity, and variety from all the functional areas, than on the mechanical tasks to collect data, and manually process them (Bergmann et al., 2020; Chapman \& Kihn, 2009; Vitale et al., 2020). Such changes moved the role from an initially operational level described as a "bean counter", "score keeper" or even "watchdog" to a strategic position called a "business partner", "consultant" or "business advisor" (Baldvinsdottir et al., 2009; Granlund \& Lukka, 1997; Pasch, 2019; Yazdifar \& Tsamenyi, 2005). The changes in the discipline progressively shifted the focus of decisions from an almost exclusive financial perspective to an integrated view of a company that produces information to support decision processes leading to strategic actions (Quattrone, 2016) and recognizes a purposeful influence in the organizational behavior in the design of management control systems (MCS) (Kaplan \& Norton, 1996, 2008).

The cost accounting specialization soon evolved into managerial accounting and management control, thereby launching accounting analysts to tactical and strategic levels (Colignon \& Covaleski, 1988; Granlund \& Lukka, 1997; Henttu-Aho, 2016). The new position both supposes the facilitation of information for decision making and ensures corporate integrity in the financial, customer, supplier, environmental and regulatory domains, thereby shaping and impacting the organizational dynamics of planned performance and results. Alternatively, the emergence of this role has been associated with the idea of the cybernetic control of MCSs implemented simultaneously in a number of processes and areas of corporate performance to provide alerts and align the use of resources. In this view, controllers are responsible for the design, implementation and proper functioning of the MCS and for the opportune production and use of information. 
The emergence of controllers is facilitated by the availability of data and computer technologies, but it is mainly explained by the increasing need to control and maintain the consistency of decisions, actions, resources and objectives in dynamic business environments. Hartman and Maas (2011) propose that the controller's role is to ensure the rationality and accountability of corporate decisions, thus making this role crucial when companies face crises. In a sense, controllers could be seen as a necessary and functional barrier to business agility, since they may restrict the freedom of managers (Ezzamel \& Burns, 2005) and permanently challenge business performance and results (Johnston et al., 2002); however, the role can be perceived as functional if it appropriately aims to ensure that risks are managed to achieve company endurance and results, according to the corporate context and needs (Aaltola, 2019).

\section{Conceptualization of the controller role}

Along with the evolution of the field and the changing organizational dynamics, the skills, tools and capabilities needed by a professional in charge of management control functions contains ambiguities, complexities and challenges to be solved by companies and professionals (Burns \& Baldvinsdottir, 2005; Byrne \& Pierce, 2018). The available literature on controllers and managerial accountants contains a large collection of responsibilities, performance areas and archetypes associated with the role, but it has not yet provided clear distinctions of the archetypes or indicated which type best fits a given context. A few studies have explored and qualitatively analyzed the controller role beyond the usual dichotomy of bean counters and business partners, and these studies agree on the need to further understand the role (Baldvinsdottir et al., 2009; Byrne \& Pierce, 2007; de Loo et al., 2011; Hopper, 1980; Lambert \& Sponem, 2012) and to deepen the understanding of the company-individual dynamics that shape the roles of controllers (Hopper, 1980; Lambert \& Sponem, 2012). The main and most generic role of controllers is to deploy the corporate strategy (Kaplan \& Norton, 2008); thus, the responsibilities defined for the role are the following: a) provide information to support decision making, b) help to reduce the divergence of individuals' and units' objectives with respect to the organizational goals, and c) supervise the use of resources to guarantee competitiveness. In these tasks, significant attention is paid to using accounting and financial information to produce reports for insiders, such as managers and company executives (managerial accounting), and for outsiders, such as shareholders, financial institutions and supervising institutions (financial accounting). The controller must also consider using nonfinancial and qualitative measures to support decision making and to participate in the monitoring, consulting, coordination and management of change at different organizational levels (Bollecker, 2007). Thus, the MCS becomes a tailor-made function for the particular organizational context, stage and leadership at a given point in time, which is the reason why the role has been identified with a number of archetypes. To customize the role, specific tasks focus on planning, monitoring, reporting, data analysis and interpretation, performance assessment and consulting; however, these tasks are emphasized or reduced according to the stakeholders' needs and culture (Goretzki et al., 2018). In the US, the role seems to be oriented more towards financial monitoring, while in some European regions, 
controllers are not responsible for financial accounting or reporting. In France, controllers are strongly related to budgeting, managerial accounting, statistical and economic analyses and long-term planning (Azan \& Bollecker, 2011; Guenther, 2013); however, in the UK, the focus is on financial discipline, and in Germany, the focus is on operational quality and safety (Janin, 2017). Such theoretical, cultural and practical differences represent a challenge for the definition and construction of archetypes and the interaction of individuals who work as controllers and the companies that hire them to deploy their corporate strategies (Byrne \& Pierce, 2018).

Different criteria could be used to conceptualize the types of controllers. A first distinction is found in Anthony (1965) and is followed by a number of publications (Järvenpää, 2007; Kaplan \& Norton, 2008; Ye et al., 2009) based on the organizational approach to the MCS. The reports indicate that organizations can be reactive and operational about management control, focusing mainly on using accounting information systems with past data to measure performance (Argyris \& Schon, 1974). Conversely, organizations can be proactive and strategic by escalating the scope of the area to include the modeling of future behavior and the measurement of organizational results as a continuous process to effectively deploy the business strategy with feed forward information, cultural/organizational design and behavioral influence (Flamholtz et al., 1985; Merchant, 1985).

More criteria to describe the role based on classifications (Table 1) have been provided by several theorists (Baldvinsdottir et al., 2009; de Loo et al., 2011; Goretzki et al., 2013; Granlund \& Lukka, 1997; Indjejikian \& Matějka, 2006; Sathe, 1983; Seal, 2006); these theorists distinguished controllers using a monitoring function where the technical abilities are the key to analyzing and processing the quantitative indicators to ensure the accuracy of financial information. Conversely, controllers can be defined as a service function, where the business view, communicational abilities, and interpersonal skills dominate in the role of controllers to assist the executive leaders in strategic decisions regarding business strategies and plans.

Table 1. Types of controllers by organizational approach to management control

\begin{tabular}{|l|c|c|c|c|c|c|c|c|c|c|}
\hline & $\begin{array}{c}\text { Opera- } \\
\text { tional } \\
\text { \& reac- } \\
\text { tive }\end{array}$ & $\begin{array}{c}\text { Stra- } \\
\text { tegic } \\
\text { \& pro- } \\
\text { active }\end{array}$ & $\begin{array}{c}\text { Moni- } \\
\text { toring }\end{array}$ & $\begin{array}{c}\text { Ser- } \\
\text { vice }\end{array}$ & $\begin{array}{c}\text { Centra- } \\
\text { lized }\end{array}$ & $\begin{array}{c}\text { De- } \\
\text { centra- } \\
\text { lized }\end{array}$ & $\begin{array}{c}\text { Ope- } \\
\text { ratio- } \\
\text { nal effi- } \\
\text { ciency }\end{array}$ & $\begin{array}{c}\text { Busi- } \\
\text { ness } \\
\text { value }\end{array}$ & Past & $\begin{array}{c}\text { Fu- } \\
\text { ture }\end{array}$ \\
\hline $\begin{array}{l}\text { Business Partner } \\
\text { (Goretzki et al., } \\
\text { 2013; Meijerink, } \\
\text { 2016; Siegel } \\
\text { et al., 2003) }\end{array}$ & $\pi$ & & & & & & & & \\
\hline $\begin{array}{l}\text { Business } \\
\text { Advocate } \\
\text { (Jablonsky et al., } \\
\text { 1993) }\end{array}$ & & & & & & & & & & \\
\hline $\begin{array}{l}\text { Consultant or } \\
\text { Advisor } \\
\text { (Holm \& Thor- } \\
\text { stensson, 2013) }\end{array}$ & & & & & & & & & & \\
\hline
\end{tabular}


End of Table 1

\begin{tabular}{|c|c|c|c|c|c|c|c|c|c|c|}
\hline & $\begin{array}{c}\text { Opera- } \\
\text { tional } \\
\& \text { reac- } \\
\text { tive }\end{array}$ & $\begin{array}{l}\text { Stra- } \\
\text { tegic } \\
\text { \& pro- } \\
\text { active }\end{array}$ & $\begin{array}{l}\text { Moni- } \\
\text { toring }\end{array}$ & $\begin{array}{l}\text { Ser- } \\
\text { vice }\end{array}$ & $\begin{array}{c}\text { Centra- } \\
\text { lized }\end{array}$ & $\begin{array}{l}\text { De- } \\
\text { centra- } \\
\text { lized }\end{array}$ & $\begin{array}{c}\text { Ope- } \\
\text { ratio- } \\
\text { nal effi- } \\
\text { ciency }\end{array}$ & $\begin{array}{l}\text { Busi- } \\
\text { ness } \\
\text { value }\end{array}$ & Past & $\begin{array}{l}\text { Fu- } \\
\text { ture }\end{array}$ \\
\hline $\begin{array}{l}\text { Business Unit } \\
\text { Controller } \\
\text { (ten Rouwelaar } \\
\text { et al., 2008) }\end{array}$ & & & & & & $\pi$ & & & & \\
\hline $\begin{array}{l}\text { Financial } \\
\text { Controller } \\
\text { (Graham et al., } \\
\text { 2012; Granlund } \\
\text { \& Lukka, 1997) }\end{array}$ & & & $\kappa$ & & $\kappa$ & & $\kappa$ & & $\kappa$ & $\pi$ \\
\hline $\begin{array}{l}\text { Navigator } \\
\text { (Goretzki et al., } \\
\text { 2013) }\end{array}$ & & & & $\pi$ & & $\pi$ & & & & \\
\hline $\begin{array}{l}\text { Service aid } \\
\text { (Hopper, 1980) }\end{array}$ & & & & $\pi$ & & & & & & \\
\hline $\begin{array}{l}\text { Watchdog - } \\
\text { Watchmen } \\
\text { (Verstegen et al., } \\
\text { 2007) }\end{array}$ & & & $\kappa$ & & & & & & & \\
\hline $\begin{array}{l}\text { Corporate } \\
\text { Policeman } \\
\text { (Hartmann \& } \\
\text { Maas, 2011; } \\
\text { Jablonsky et al., } \\
\text { 1993) }\end{array}$ & & & $\kappa$ & & & & $\kappa$ & & & \\
\hline $\begin{array}{l}\text { Bean counter } \\
\text { (Friedman \& } \\
\text { Lyne, 2001; } \\
\text { Granlund \& } \\
\text { Lukka, 1997) }\end{array}$ & $\kappa$ & & $\kappa$ & & & & & & $\kappa$ & \\
\hline $\begin{array}{l}\text { Score/Book- } \\
\text { keeper } \\
\text { (Goretzki et al., } \\
\text { 2013; Hopper, } \\
\text { 1980; Meijerink, } \\
\text { 2016) }\end{array}$ & $\kappa$ & & $\kappa$ & $\pi$ & & & & & $\kappa$ & \\
\hline $\begin{array}{l}\text { Historian - } \\
\text { Reporter } \\
\text { (Granlund \& } \\
\text { Lukka, 1997; } \\
\text { Verstegen et al., } \\
\text { 2007) }\end{array}$ & & & & & & & $\kappa$ & & $\kappa$ & \\
\hline
\end{tabular}

After combining the many available criteria, we identify four different types of controllers and label them as information source, operational controller, coordinator, and business partner, which are used to frame the archetypes found in the literature. The four types of controllers are incremental in terms of their responsibilities, required abilities, and organiza- 
tional levels in which they are positioned. The framework was first evaluated and validated by three scholars in individual sessions and by managers in an executive master's program in management control. These participants suggested specifications based on the association of the abilities and responsibilities with the four profiles. The framework presented in the figure is the final validated version. Here, we describe the types in detail, associating the main features and responsibilities to each type and organizing the profiles in a conceptual map, presented in Figure 1.

The first and most elementary type of controller combines the archetypes identified in the literature as the bean counter, scorekeeper, and historian. S/he is expected to influence the design and be responsible for the exploitation of the information systems in the organization (Burns et al., 2014), for the construction of standard reports for internal and external users, for the construction of ad hoc information on demand to represent the economic state of the company, and for the design and maintenance of the financial-cost-budget-accounting systems. To succeed in the position, this controller needs to master the technical skills related to cost control, use of information systems, data analysis, and report design, and the controller must also be proficient in communicating sensitive information with an internal user orientation. We identify this type of controller as the information source.

A second type of controller uses the information to monitor business processes, operations and overall efficiency of the resources' use, hence emphasizing planning and monitoring responsibilities. This type is usually presented in the literature under the archetypes of corporate policeman, watchdog, or watchmen. The main tasks for this type are the analysis of budget construction and execution, business process optimization, and operation planning and monitoring. The competencies required for this type of role are process optimization and resource organization skills, in addition to being an expert in business operations. The foci of the communications are expanded to the external users of information (regulators, auditors, shareholders, customers, suppliers, etcetera) to gain credibility in the entire organization, and we call this type the operational controller.

A third type of controller is the coordinator, who uses information and managerial tools to align resources and people in a proactive manner. The responsibilities of a coordinator include designing and maintaining mechanisms to measure and influence performance, facilitating and supporting communication and coordination, and safeguarding the strategic alignment of the different business units, including departments and individuals. With a more complex set of abilities and skills, the coordinator should be an expert in the business sector/domain where the company operates, understand how to influence human behavior, excel at negotiation, and exhibit systemic thinking. The archetypes in the literature that relate to this type are the navigator, financial controller and service aid.

A business partner controller is proactive and a strategist and is also referred to as a consultant, advocate or business advisor. Beyond controlling, the business partner is expected to develop and use managerial and business skills and be responsible for ensuring the organizational sustainability and growth to protect the interests of stakeholders. S/he participates in the formulation and design of the corporate strategy and initiatives and must ensure the decision making objectivity at the C-level. The business partner is defined by his/her commercial and entrepreneurial thinking, independence, persuasion, influence and leadership. 


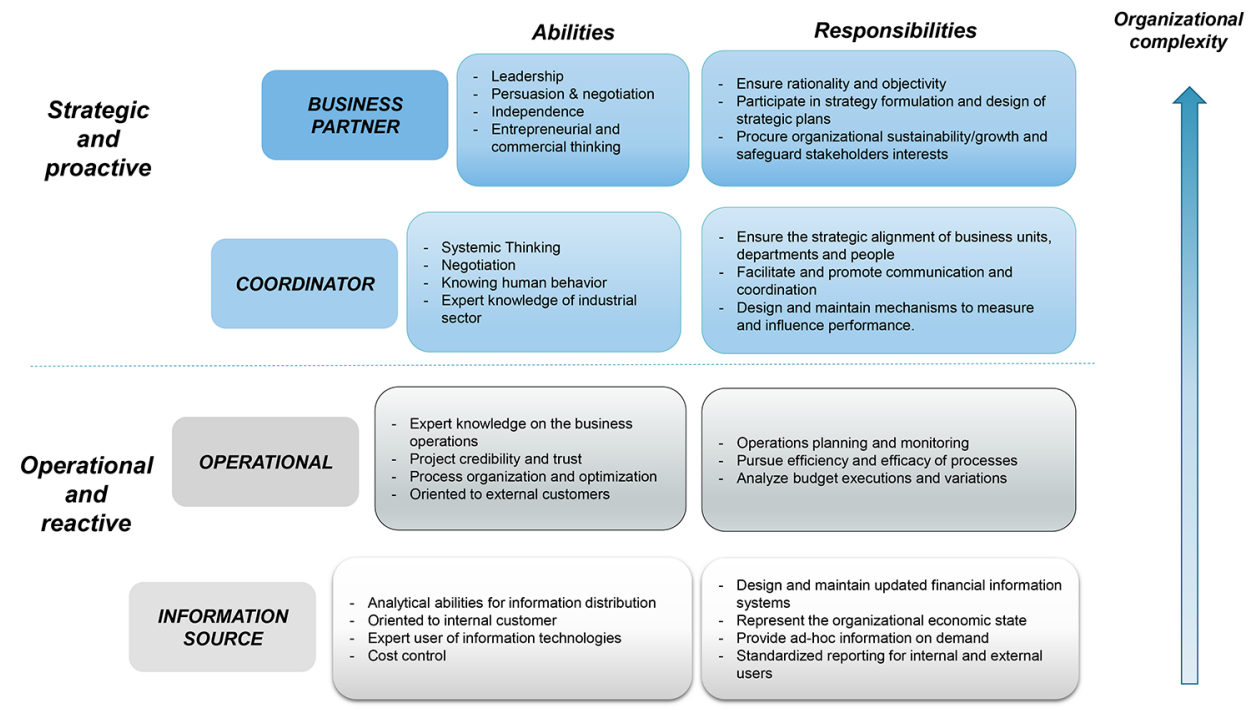

Figure 1. Conceptual framework for the controller profiles

\section{Classification of controllers}

The framework is used as the theoretical basis for the classification of a sample of professional controllers. The definitions of controller profiles are used to categorize the sample of individuals obtained by a survey. Then, a classification procedure is implemented based on the work of La Paz et al. (2019), whose novel clustering method groups the sample using profiles with a semidefined set of variables and allows the undefined variables to iterate and fill the null values as the algorithm learns. Finally, we compare the classifications of the datasets and discuss the results.

\subsection{Survey construction}

The survey translated the framework's elements into multiple-choice questions. Each individual was asked for information about their abilities, responsibilities and agenda priorities, as well as about their organization and position, like company size, sales level, span of control, hierarchical level, participation in the company's strategy definition, years of experience as a professional and as a controller, and academic background. We retrieved these data based on the results obtained by Rieg (2018), who also stated the need for more studies about the relations of these variables and the type of controller roles.

\subsection{Obtaining the sample}

An invitation to participate in the survey was sent to controllers hired in different industrial sectors. The controllers were identified first using the personal contacts of the authors and then using an online professional network platform. An approximate response rate of $12 \%$ yielded 45 complete responses, obtaining a dataset with 58 variables. 
Using the International Standard Industrial Classification (ISIC), most of the surveyed controllers worked in companies in wholesale and retail trade (section G), transportation and storage (section $\mathrm{H}$ ), and agriculture, forestry and fishing (section A). Using the European Commission's definition of enterprise sizes, $60.0 \%$ of the controllers worked in large companies (more than 249 employees), and the rest did in small and medium size enterprises. Considering sales per year, $75.6 \%$ of the sample worked in companies with sales above USD\$ 4 million, 2.2\% were hired by enterprises with sales less than USD\$ 1 million, and the rest worked in organizations with sales between those thresholds.

\subsection{Semisupervised Clustering Algorithm}

Data-based approaches can be used to cluster observations into groups. Clustering algorithm is a well-known technique, developed in the data science fields, where unlabeled data is fed into an algorithm for identifying untargeted observations from patterns (Mirkin, 2016). The literature documents several clustering algorithms and approaches. To name a few, the hierarchical procedures group the elements of a sample considering the similarities and differences (Johnson, 1967); the density-based assess the compliance of a minimal number of neighbors within a radius (Ester et al., 1996); and, with a simpler approach, the centroid-based algorithms cluster observations identifying a predefined $k$ number of representatives and assign each observation to one centroid - $k$-means is one of the most used (Arora \& Varshney, 2016).

According to our research objectives, it is apparent that $k$-means, with a semisupervised approach, is the most suitable. There are two main reasons. First, this approach permits to semi-define initial centroids, and then, each observation is assigned to one group as the algorithm identifies the final centroids' values dynamically by analyzing the data. Second, its simplicity and the current computing power of technology makes it feasible to create several grouping solutions (partitions) and identify a final clustering considering the whole set of partitions by a voting system, obtaining hence a better-quality solution compared to a single grouping. It can be tempting to relate such description to an ensemble clustering algorithm (EC) (Alqurashi \& Wang, 2019; Fred \& Jain, 2005), however, it has some differences. The major is that most of EC algorithms, after obtaining the set of partitions, find a final partition by using a consensus function, such as the cooccurrence in grouping amongst pairs of elements, and then, cluster objects according to their similarities/differences, like the hierarchical clustering's approaches (notice that the results of the consensus function are used for identifying the final partition, hence, the original features are not considered). In our case, if an EC approach was used, during the consensus stage, the relationships between the controller (elements to group) and semi-predefined profiles (centroids) are somehow lost.

Given the exploratory nature of our controller profile framework, we followed the method presented in La Paz et al. (2019) by implementing a semisupervised clustering algorithm based on $k$-means, in order to classify a dataset of controllers into the profiles presented and explained in Section 2, considering each controller profile as a centroid, and identify their new attributes through the clustering process, this is, $k$ centroids are partially defined in the conceptual framework for the controller profiles. Our semisupervised clustering method assumes that $k$ centroids start with $n<m$ defined attributes and $m-n$ are unknown, where $m$ is the total number of features for each $z$ observation in the $X$ dataset, therefore, each 


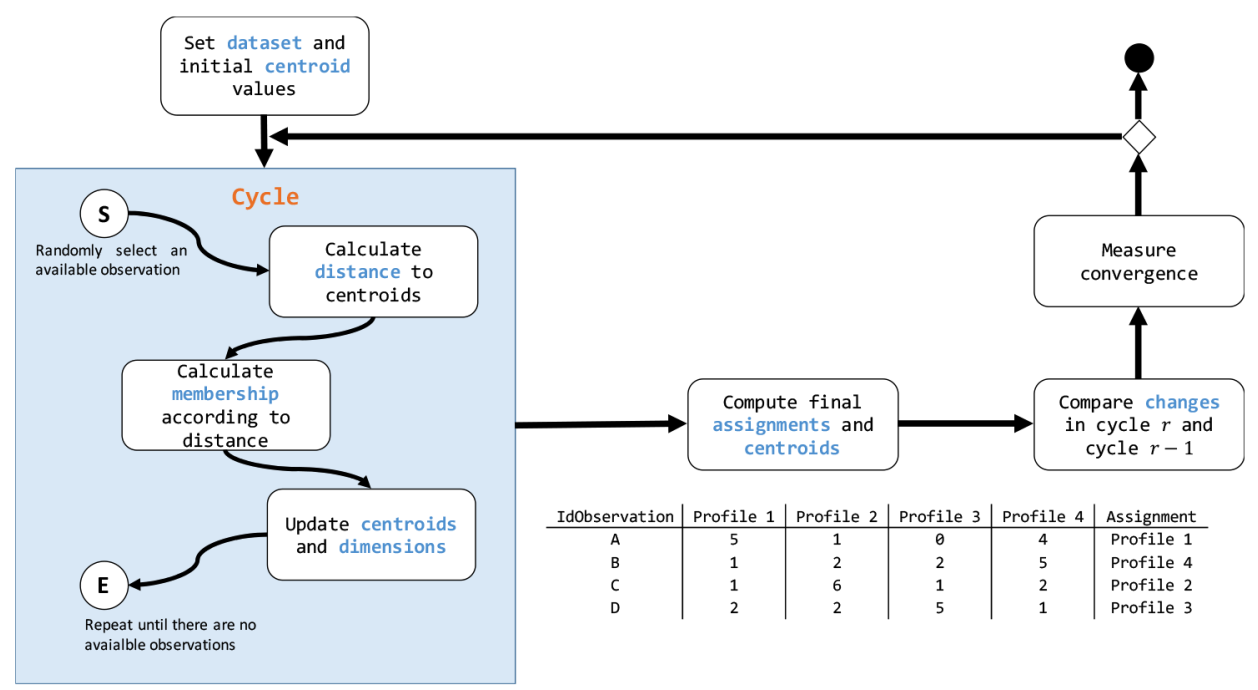

Figure 4. Clustering scheme of the semisupervised $k$-means method

\subsection{Semisupervised classification application}

The data preprocessing and the semisupervised algorithm were implemented in RStudio, an integrated development environment (IDE) suite for $\mathrm{R}$ programming language. Our method requires the use of numerical variables, hence, the sample dataset was transformed into a numeric matrix and divided into two datasets: one for organizational definitions and the other for individuals' characteristics. The organizational definitions dataset was composed of 24 variables on corporate controllers' responsibilities (represented by the controller's agenda), the role in the company, span of control, organizational position, and participation in defining the corporate strategy. The individuals' characteristics dataset included 26 variables about abilities, years of professional experience and in the role, and academic backgrounds.

In the preprocessing procedure, all the variables were transformed into a $[0,1]$ range for scale effects reduction, and we set known and null subsets for each dataset. In the case of individuals' characteristics, the known values were the abilities identified from the survey, and for the organizational definition, the known values were the responsibilities in the dataset. The remaining variables set as null were the role in the company, span of control, organizational position, years of experience, and participation in defining the corporate strategy from the organizational definition dataset and years of experience and academic backgrounds from the individuals' characteristics dataset.

Once the data were transformed and the known and null variables set, the algorithm started to cluster each observation to their dominant profiles represented by the centroids with the known variables. In our implementation, we set $\alpha$ as 0.05 , and the performances were better than La Paz et al. (2019), since our algorithm reached convergence in the classification process after the $15^{\text {th }}$ and $21^{\text {st }}$ partition (see Figure 5) compared to the $150^{\text {th }}$ in their implementation. These results are discussed in the following section. 


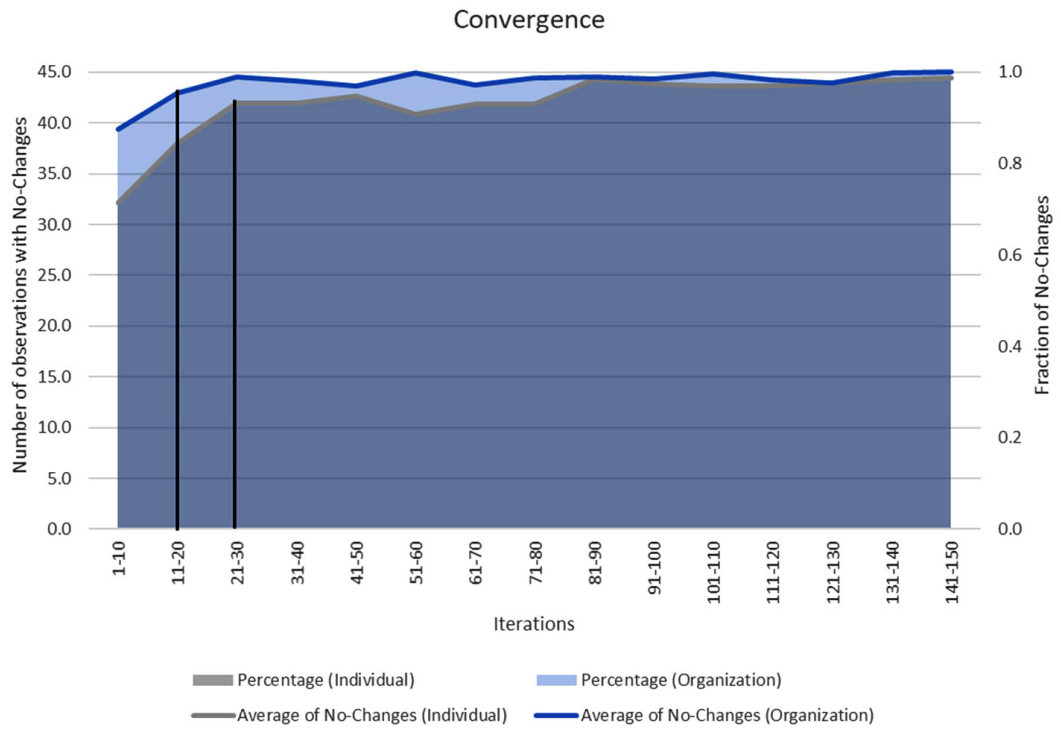

Figure 5. Convergence in the classification using the organizational definitions and individuals' characteristics

To associate each observation to the clusters, we calculated a score named the membership degree that was obtained using the classification process data. The membership degree was calculated for each observation and each profile, where the sum of the four scores equals one, indicating how much an observation pertains to each type of controller. Then, the dominant controller profile is determined according to the highest membership degree among the four scores. By analyzing the membership degrees, one could evaluate the differences
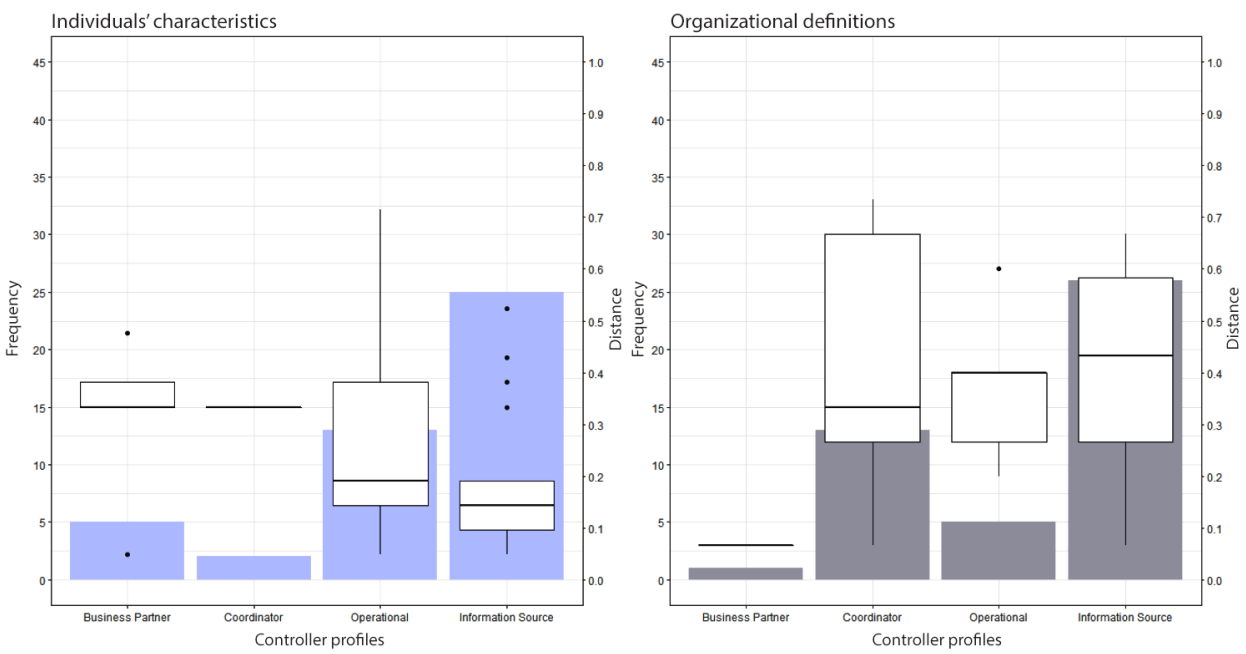

Figure 6. Frequency and dispersion of the distance between the first and second most dominant profiles for each group 
between the most dominant - or highest membership degree - and the second most dominant - second highest membership degree - to analyze the dominance of the profile. The analysis was performed on the classification of individuals and companies' requests as follows. First, we calculated the difference as the simple distance between the membership degrees of the two most dominant profiles and then generated a boxplot chart as a dispersion indicator. This boxplot provides information in three ways: (1) the boxes indicate the first ( $25^{\text {th }}$ percentile - bottom line), second $\left(50^{\text {th }}\right.$ percentile - middle line $)$, and third $\left(75^{\text {th }}-\right.$ top line) quartile of profile dominance distance; (2) the vertical lines represent the lowest and highest distance between two most dominant profiles using $\pm 1.5 \mathrm{IQR}$ (interquartile range or distance between the first and third quartiles); and (3) the points show the outliers above or below the \pm 1.5 IQR extremes, where only three clusters show outliers profile dominances distances. Additionally, we used the clusters' size for create a bar chart (related to frequency axes) and put together with the boxplot chart (related to distance axes). Both charts were generated using RStudio and ggplot library (see Figure 6).

\section{Contrasting the controller clusters for individuals and companies}

The classification processes identified a majority of the information source cluster as the most commonly dominant profile. The least dominant profiles in the classification process were the business partner in the organizational definitions, and the coordinator, in the individuals' characteristics. The results represent the dominant controller profiles that companies emphasize and that individuals present in our sample, and they allow us to reveal the matches and mismatches between companies' definitions and the hired individuals' profiles. A match is defined as a company hiring an individual who coincides with the dominant profile that the company requires, while a mismatch indicates that a company hires a person with abilities corresponding to a different profile than the set of features that the company delineates for the controller position.

The clustering process shows that matches were identified in the information source and operational groups. For the most coincident profile, similar number of observations are found in the individuals' and the organizations dataset, but less than half of the individuals and companies match. There are more individuals labeled as business partner controllers than companies that require this type of controller, whereas there are more companies in need for a coordinator controller than individuals in this group. In the case of operational controllers, more individuals present the dominant profile than companies requiring one. Figure 7 shows the classification frequencies in the groups, indicating the matched and mismatched proportions for each profile.

A one-to-one match analysis reveals that $42 \%$ of the companies and individuals from the sample match well (most of them from the information source controllers), and a concerning $58 \%$ do not match, i.e., companies define a controller position, but they hire a person with abilities that do not fit the profile, or individuals work for companies that appreciate skills that are different from theirs.

Table 2 further details the matches and mismatches in the sample, where the diagonal indicates the matches between companies' needs and individuals' abilities, and the cells above 


\begin{tabular}{|c|c|c|c|c|c|}
\hline Controller Profile & & Frequency & & Match & \\
\hline $\begin{array}{c}\text { Business } \\
\text { Partner }\end{array}$ & $\begin{array}{l}\text { Organizational } \\
\text { definitions } \\
\text { Individuals' } \\
\text { characteristics }\end{array}$ & & 1 & $\begin{array}{cc}0 \\
1 \\
\text { Match : } \\
\text { Mismatch: } & 6\end{array}$ & $\begin{array}{l}5 \\
(0 \%) \\
(100 \%)\end{array}$ \\
\hline Coordinator & $\begin{array}{l}\text { Organizational } \\
\text { definitions } \\
\text { Individuals' } \\
\text { characteristics }\end{array}$ & & $\begin{array}{l}13 \\
2\end{array}$ & $\begin{array}{c}\bigcirc_{13} \\
\text { Match : } 0 \\
\text { Mismatch: } 15\end{array}$ & $\begin{array}{l}2 \\
(0 \%) \\
(100 \%)\end{array}$ \\
\hline Operational & $\begin{array}{l}\text { Organizational } \\
\text { definitions } \\
\text { Individuals' } \\
\text { characteristics }\end{array}$ & & 13 & $\begin{array}{ll}3^{2} \bigcirc \\
\text { Match }: & 3 \\
\text { Mismatch: } & 12\end{array}$ & $\begin{array}{l}(20 \%) \\
(80 \%)\end{array}$ \\
\hline $\begin{array}{l}\text { Information } \\
\text { Source }\end{array}$ & $\begin{array}{l}\text { Organizational } \\
\text { definitions } \\
\text { Individuals' } \\
\text { characteristics }\end{array}$ & & 26 & $\begin{array}{l}\text { Match : } 16 \\
\text { Mismatch: } 19\end{array}$ & $\begin{array}{l}(46 \%) \\
(54 \%)\end{array}$ \\
\hline
\end{tabular}

Figure 7. Classifications, matches and mismatches of controllers per type in each dataset

or below reveal mismatches. Indeed, above the diagonal, one information source controller is hired as operational controller, seven as coordinators, and one as business partner, while five operational controllers are contracted as coordinators. The values under the diagonal of the table identify that five operational controllers were hired as information source, one coordinator work as information source and one works as an operational, four business partners work as information sources and one business partner work as coordinator.

In addition to the classification of individuals and organizations' definitions of the role, the clustering technique also defines a stable set of variables that best describe the clusters,

Table 2. Match according to dominant profiles in each dataset

\begin{tabular}{|c|c|c|c|c|c|c|}
\hline & \multicolumn{4}{|c|}{ Organizational definitions } & \multirow[b]{2}{*}{ Total } \\
\hline & & $\begin{array}{c}\text { Information } \\
\text { Source }\end{array}$ & Operational & Coordinator & $\begin{array}{c}\text { Business } \\
\text { Partner }\end{array}$ & \\
\hline \multirow{5}{*}{ 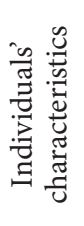 } & Information Source & 16 & 1 & 7 & 1 & 25 \\
\hline & Operational & 5 & 3 & 5 & 0 & 13 \\
\hline & Coordinator & 1 & 1 & 0 & 0 & 2 \\
\hline & Business Partner & 4 & 0 & 1 & 0 & 5 \\
\hline & Total & 26 & 5 & 13 & 1 & \\
\hline
\end{tabular}


where the final values for the subset of variables initially set as null are particularly interesting. The years of experience as a professional and controller show that business partners are the most experienced and the operational controllers are the least experienced. Additionally, the majority of the observations in the business partner and coordinator groups have academic backgrounds in management, while the majority of the operational controller and information source groups have academic backgrounds related to process and accounting disciplines. Furthermore, the results indicate that business partners and coordinators report mainly to CEOs or company directors and actively participate in the formulation of their company's strategy, whereas operational and information source controllers report to the CFO, indirectly participate in the strategy formulation process, and do not actively participate or influence it.

\section{Discussion}

Identifying the right person for the job is critical for the well-functioning of organizations. This match is especially critical at the C-Level where high-impact decisions are made. In the areas of controlling and managerial accounting, the discussion is interesting given the rapid evolution of the areas in the recent decades. Matching a position with the right personal and technical abilities facilitates the planning, monitoring, controlling and performance processes according to the corporate vision to achieve with efficiency the alignment and strategy deployment. In contrast, a deficient definition of the role or filling the role with the wrong over/ underqualified person will likely hinder the controlling process, generating frustration and underperformance in companies and individuals.

The results are consistent with the literature about the mismatches between the individuals' abilities and companies' approach to controlling (Rieg, 2018). In a few cases, companies hired controllers with strategic and proactive abilities and skills, but then assigned them reactive and operational control responsibilities. Such cases could be regarded as overqualified professionals in the role or underutilized skills by companies. On the other hand, more frequently in our sample, companies shape the role as a strategic and proactive approach to control but hire professionals with strong technical skills but insufficient managerial, communication and interpersonal abilities. The latter would not produce the expected results from the controlling process, since the proactive and strategic definitions require networking, leadership and other managerial, communication and interpersonal abilities to be successfully deployed. Additionally, the simplistic dichotomy of controller types (the bean counter and business partner) is questioned by the hybrid or intermediate profiles (Karlsson et al., 2019; Rieg, 2018).

Mismatches can be the result of different causes (Goretzki et al., 2013). One cause could be the market forces, and if we considered individuals as the supply and companies' requirements as the demand for types of controllers, our sample could match better by redistributing the professionals in the companies according to the dominant profiles' definitions. There can be market gaps if there are not enough professionals with the given abilities and skills to meet the needs of companies for that specific type. In the studied sample, this would be the case for coordinators, where more companies desire this type of role (13 cases), but 
few individuals ( 2 professionals) possess its dominant characteristics. The market forces are dynamic, as the companies' approaches to control can change with the evolution of the technological, growth, maturity, legal and normative environments and a wide array of variables. Individuals can also change by shaping their professional careers and improving their abilities and skills through practice and specialization. The recruitment and selection, or the headhunting processes, can help to solve mismatches, but gaps may require the intervention of more actors, such as educational institutions, where individuals could develop the appropriate skills for the different types of controller roles in response to the market demands and requirements.

This research presents a conceptual map, which was built on the basis of previous publications, that classifies roles and individuals into four distinct types of controllers. The four types are theoretical, but companies and individuals commit to responsibilities from the different types of controllers, and they interactively use the abilities of information sources and operational controllers or business partners with coordinators, associated here with the dominant clusters.

\section{Conclusions}

The approach of companies and professionals to the controlling function has changed and evolved in the last decades and will continue to do so with the pervasiveness of digital transformations and process automation. From the organizational point of view, the controlling function became a permanent process that facilitates the compliance to norms, the deployment of a business strategy and the survival of companies that strive in an increasingly complex environment flooded with big data. Professionals with control responsibilities need to develop skills and abilities to exploit information technologies to manage the financial, managerial and cost accounting systems and to influence people's behavior and effectively communicate with different actors at all corporate levels. Many other forces can be mentioned with respect to the evolution of control as one key managerial function; however, the above can be decided by companies and individuals themselves, while others are external, and companies do not directly impact them.

Our study conceptualized the different types of controller profiles required by organizations and performed by professionals in the field. In addition, we introduced and empirically tested a conceptual framework for controller profiles. The framework was used to map a sample of controllers by their abilities and relevant personal characteristics for the job; on the other hand, the organizational emphases define a given controller profile that is mapped mainly by using the responsibilities and organizational structure for the position. The mapping was conducted by applying semisupervised clustering techniques to a sample that assigned the observations to the dominant profiles. The dominant profiles are contrasted to analyze the matches between organizational preferences and the hired professionals. The evidence shows that there are important mismatches and an operational rather than a strategic emphasis on the controlling function. The clustering also allowed us to identify the over and underqualified professionals based on the responsibilities assigned by companies, which could be one factor that explains why companies do not always reap the benefits of management control. 
The results from this research have multiple theoretical and practical implications. The conceptual framework - although not prescriptive - organizes the current controller archetypes found in the literature in an aggregate manner such that companies and individuals can use it to evaluate what type of controller they need or belong to, respectively, and then adjust the role definition and career development. Additionally, scholars can use the framework to question the direction of the management control discipline and adjust their research agendas. Universities and educational institutions may analyze and eventually update their academic programs to respond to the market's needs, or decide which competences and subjects to teach in their undergraduate and graduate programs. Finally, headhunting companies and recruitment and selection processes may use this framework to better match companies and individuals. Future research avenues can be explored to study the effects of the selection of over/underqualified controllers, the actions or strategies to prevent/minimize the mismatches in the selection and recruitment of controllers, and the impacts of the controller type on the effectiveness of the controlling function.

Our results should be carefully interpreted, since they are based on an exploratory but not confirmatory approach. Additionally, the information collected in the sample is self-reported by the individuals, and a number of other market forces, such as wage level, employment rates, regulations that mandate compliance reports, maturity of the financial system and entrepreneurial development, are not included in the study. Thus, the information could be biased with respect to the strengths they claimed to have or the importance of the activities assigned by their companies for which they are responsible and accountable, which are dynamic, difficult to obtain, and depend on external market forces. Furthermore, the semisupervised algorithm needs significant computational resources in order to minimize the effect of the initial seed in the mapping process, especially when stricter convergence criteria are set. Also, as a semisupervised method, it contains some limitations of supervised and unsupervised learning algorithms, e.g., obtaining unstable results, because final classifications are affected by input dataset and setting. Even so, this is an interesting proposal to identify the actual control approaches in companies and the dominant abilities of individuals. This study aims to open new lines of research to extend the understanding of the roles of controllers and their evolution towards finding a better match between the organizational definitions and the emphases of management control with the professionals' abilities.

\section{Author contributions}

Author Contributions: Conceptualization, Ariel La Paz and Daniela Gracia; Methodology, all authors; Data Curation, Daniela Gracia and Jonathan Vásquez; Formal Analysis: all authors; Writing, all authors; Coordinator, Ariel La Paz; Validation: Daniela Gracia.

\section{Disclosure statement}

Conflicts of Interest: The authors declare no conflicts of interest. 


\section{References}

Aaltola, P. (2019). Strategic thinking and accounting: potentials and pitfalls from a managerial perspective. Journal of Management Control, 30(3), 323-351. https://doi.org/10.1007/s00187-019-00285-w

Alqurashi, T., \& Wang, W. (2019). Clustering ensemble method. International Journal of Machine Learning Cybernetics, 10(6), 1227-1246. https://doi.org/10.1007/s13042-018-0807-8

Anthony, R. N. (1965). Planning and control systems: A framework for analysis. Division of Research, Graduate School of Business Administration, Harvard University.

Argyris, C., \& Schon, D. A. (1974). Theory in practice: Increasing professional effectiveness. Jossey-Bass.

Arora, P., \& Varshney, S. (2016). Analysis of k-means and k-medoids algorithm for big data. Procedia Computer Science, 78, 507-512. https://doi.org/10.1016/j.procs.2016.02.095

Azan, W., \& Bollecker, M. (2011). Management control competencies and ERP: an empirical analysis in France. Journal of Modelling in Management, 6(2), 178-199. https://doi.org/10.1108/17465661111149575

Baldvinsdottir, G., Burns, J., Nørreklit, H., \& Scapens, R. W. (2009). The image of accountants: from bean counters to extreme accountants. Accounting, Auditing \& Accountability Journal, 22(6), 858882. https://doi.org/10.1108/09513570910980445

Bergmann, M., Brück, C., Knauer, T., \& Schwering, A. (2020). Digitization of the budgeting process: determinants of the use of business analytics and its effect on satisfaction with the budgeting process. Journal of Management Control, 31, 25-54. https://doi.org/10.1007/s00187-019-00291-y

Bollecker, M. (2007). La recherche sur les contrôleurs de gestion: état de l'art et perspectives. Comptabilité-Contrôle-Audit, 13(1), 87-106. https://doi.org/10.3917/cca.131.0087

Burns, J., \& Baldvinsdottir, G. (2005). An institutional perspective of accountants' new roles-the interplay of contradictions and praxis. European Accounting Review, 14(4), 725-757. https://doi.org/10.1080/09638180500194171

Burns, J., Warren, L., \& Oliveira, J. (2014). Business partnering: Is it all that good? Controlling Management Review, 58(2), 36-41. https://doi.org/10.1365/s12176-014-0907-6

Byrne, S., \& Pierce, B. (2007). Towards a more comprehensive understanding of the roles of management accountants. European Accounting Review, 16(3), 469-498. https://doi.org/10.1080/09638180701507114

Byrne, S., \& Pierce, B. (2018). Exploring management accountants' role conflicts and ambiguities and how they cope with them. Qualitative Research in Accounting \& Management, 15(4), 410-436. https://doi.org/10.1108/QRAM-11-2016-0083

Chapman, C. S., \& Kihn, L.-A. (2009). Information system integration, enabling control and performance. Accounting, Organizations and Society, 34(2), 151-169. https://doi.org/10.1016/j.aos.2008.07.003

Colignon, R., \& Covaleski, M. (1988). An examination of managerial accounting practices as a process of mutual adjustment. Accounting, Organizations and Society, 13(6), 559-579. https://doi.org/10.1016/0361-3682(88)90031-1

Colton, S. D. (2001). The changing role of the controller. Journal of Cost Management, 15(6), 5-16.

Crampton, J. V. (1970). The changing role of the Controller. University of Missouri, Columbia.

de Loo, I., Verstegen, B., \& Swagerman, D. (2011). Understanding the roles of management accountants. European Business Review, 23(3), 287-313. https://doi.org/10.1108/09555341111130263

Ester, M., Kriegel, H.-P., Sander, J., \& Xu, X. (1996, August). A density-based algorithm for discovering clusters in large spatial databases with noise. In KDD-96 Proceedings (pp. 226-231). AAAI.

Ezzamel, M., \& Burns, J. (2005). Professional competition, economic value added and management control strategies. Organization Studies, 26(5), 755-777. https://doi.org/10.1177/0170840605054598 
Flamholtz, E. G., Das, T., \& Tsui, A. S. (1985). Toward an integrative framework of organizational control. Accounting, Organizations and Society, 10(1), 35-50.

https://doi.org/10.1016/0361-3682(85)90030-3

Fourné, S. P., Guessow, D., \& Schäffer, U. (2018). Controller roles: Scale development and validation. In Performance measurement and management control: The relevance of performance measurement and management control research (pp. 143-190). Emerald Publishing Limited. https://doi.org/10.1108/S1479-351220180000033007

Fred, A. L., \& Jain, A. K. (2005). Combining multiple clusterings using evidence accumulation. IEEE Transactions on Pattern Analysis and Machine Intelligence, 27(6), 835-850. https://doi.org/10.1109/tpami.2005.113

Friedman, A. L., \& Lyne, S. R. (2001). The beancounter stereotype: towards a general model of stereotype generation. Critical Perspectives on Accounting, 12(4), 423-451. https://doi.org/10.1006/cpac.2000.0451

Goretzki, L., Lukka, K., \& Messner, M. (2018). Controllers' use of informational tactics. Accounting and Business Research, 48(6), 700-726. https://doi.org/10.1080/00014788.2017.1407627

Goretzki, L., Strauss, E., \& Weber, J. (2013). An institutional perspective on the changes in management accountants' professional role. Management Accounting Research, 24(1), 41-63.

https://doi.org/10.1016/j.mar.2012.11.002

Graham, A., Davey-Evans, S., \& Toon, I. (2012). The developing role of the financial controller: Evidence from the UK. Journal of Applied Accounting Research, 13(1), 71-88. https://doi.org/10.1108/09675421211231934

Granlund, M., \& Lukka, K. (1997). From bean-counters to change agents: the Finnish management accounting culture in transition. LTA, 3, 213-255.

Guenther, T. W. (2013). Conceptualisations of 'controlling'in German-speaking countries: analysis and comparison with Anglo-American management control frameworks. Journal of Management Control, 23(4), 269-290. https://doi.org/10.1007/s00187-012-0166-7

Hartmann, F. G. H., \& Maas, V. S. (2011). The effects of uncertainty on the roles of controllers and budgets: An exploratory study. Accounting and Business Research, 41(5), 439-458. https://doi.org/10.1080/00014788.2011.597656

Henttu-Aho, T. (2016). Enabling characteristics of new budgeting practice and the role of controller. Qualitative Research in Accounting and Management, 13(1), 31-56. https://doi.org/10.1108/QRAM-09-2014-0058

Holm, S., \& Thorstensson, D. (2013). The current state of controller roles: Underlying social factors and identity control (Master thesis). Uppsala, Sweden.

Hopper, T. M. (1980). Role conflicts of management accountants and their position within organisation structures. Accounting, Organizations and Society, 5(4), 401-411. https://doi.org/10.1016/0361-3682(80)90039-2

Indjejikian, R. J., \& Matějka, M. (2006). Organizational slack in decentralized firms: The role of business unit controllers. Accounting Review, 81(4), 849-872. https://doi.org/10.2308/accr.2006.81.4.849

Jablonsky, S. F., Keating, P. J., \& Heian, J. B. (1993). Business advocate or corporate policeman?: Assessing your role as a financial executive. Financial Executives Research Foundation.

Janin, F. (2017). When being a partner means more: The external role of football club management accountants. Management Accounting Research, 35, 5-19. https://doi.org/10.1016/j.mar.2016.05.002

Järvenpää, M. (2007). Making business partners: a case study on how management accounting culture was changed. European Accounting Review, 16(1), 99-142. https://doi.org/10.1080/09638180701265903

Johnson, S. C. (1967). Hierarchical clustering schemes. Psychometrika, 32(3), 241-254. https://doi.org/10.1007/BF02289588 
Johnston, R., Brignall, S., \& Fitzgerald, L. (2002). "Good enough" performance measurement: A tradeoff between activity and action. Journal of the Operational Research Society, 53(3), 256-262. https://doi.org/10.1057/palgrave.jors.2601217

Kaplan, R. S., \& Norton, D. P. (1996). The balanced scorecard: translating strategy into action. Harvard Business Press. https://doi.org/10.2307/41165876

Kaplan, R. S., \& Norton, D. P. (2008). The execution premium: Linking strategy to operations for competitive advantage. Harvard Business Press.

Karlsson, B., Hersinger, A., \& Kurkkio, M. (2019). Hybrid accountants in the age of the business partner: exploring institutional drivers in a mining company. Journal of Management Control, 30(2), 185-211. https://doi.org/10.1007/s00187-019-00280-1

La Paz, A., Vasquez, J., \& Miranda, J. (2019). The CIO gap and mismatch. IT Professional, 21(2), 66-72. https://doi.org/10.1109/MITP.2018.2883089

Lambert, C., \& Sponem, S. (2012). Roles, authority and involvement of the management accounting function: a multiple case-study perspective. European Accounting Review, 21(3), 565-589. https://doi.org/10.1080/09638180.2011.629415

Meijerink, N. (2016). Determinants for the role of the finance function: An empirical study of organisations in the Netherlands (MSc Business Administration). University of Twente, Amsterdam.

Merchant, K. A. (1985). Control in business organization. Financial Times/Prentice Hall.

Mirkin, B. (2016). Clustering: a data recovery approach. Chapman and Hall/CRC.

Morales, J., \& Lambert, C. (2013). Dirty work and the construction of identity. An ethnographic study of management accounting practices. Accounting, Organizations and Society, 38(3), 228-244. https://doi.org/10.1016/j.aos.2013.04.001

Pasch, T. (2019). Strategy and innovation: the mediating role of management accountants and management accounting systems' use. Journal of Management Control, 30(2), 213-246. https://doi.org/10.1007/s00187-019-00283-y

Quattrone, P. (2016). Management accounting goes digital: Will the move make it wiser? Management Accounting Research, 31, 118-122. https://doi.org/10.1016/j.mar.2016.01.003

Rieg, R. (2018). Tasks, interaction and role perception of management accountants: Evidence from Germany. Journal of Management Control, 29, 183-220. https://doi.org/10.1007/s00187-018-0266-0

Sathe, V. (1983). The controller's role in management. Organizational Dynamics, 11(3), 31-48. https://doi.org/10.1016/0090-2616(83)90004-9

Seal, W. (2006). Management accounting and corporate governance: An institutional interpretation of the agency problem. Management Accounting Research, 17(4), 389-408. https://doi.org/10.1016/j.mar.2006.05.001

Siegel, G., Sorensen, J. E., \& Richtermeyer, S. B. (2003). Becoming a business partner. Strategic Finance, 85(4), 37.

ten Rouwelaar, H. A., Bots, J., \& Vanamelsfort, M. (2008). Business unit controller involvement in management: An empirical study in the Netherlands.

https://papers.ssrn.com/sol3/papers.cfm?abstract_id $=1277863$

ten Rouwelaar, H., Bots, J., \& De Loo, I. (2018). The influence of management accountants on managerial decisions. Journal of Applied Accounting Research, 19(4), 442-464. https://doi.org/10.1108/JAAR-10-2016-0101

Verstegen, B. H., De Loo, I., Mol, P., Slagter, K., \& Geerkens, H. (2007). Classifying controllers by activities: An exploratory study. Journal of Applied Management Accounting Research, 5(2), 9-32.

Vitale, G., Cupertino, S., \& Riccaboni, A. (2020). Big data and management control systems change: the case of an agricultural SME. Journal of Management Control, 31, 123-152.

https://doi.org/10.1007/s00187-020-00298-w 
Yazdifar, H., \& Tsamenyi, M. (2005). Management accounting change and the changing roles of management accountants: a comparative analysis between dependent and independent organizations. Journal of Accounting \& Organizational Change, 1(2), 180-198. https://doi.org/10.1108/18325910510635353

Ye, Y., Zhang, Q., \& Huang, L. (2009, September 14-16). Ultimate controller, corporate government and consideration determination in the split-share structure reform. In 2009 International Conference on Management Science and Engineering - 16 th Annual Conference Proceedings, ICMSE 2009 (pp. 709-716). IEEE. https://doi.org/10.1109/ICMSE.2009.5318246

Zoni, L., \& Merchant, K. A. (2007). Controller involvement in management: An empirical study in large Italian corporations. Journal of Accounting and Organizational Change, 3(1), 29-43.

https://doi.org/10.1108/18325910710732849 